\title{
Analisa kuat tekan beton k-400 dengan campuran material pengganti cement (slag cement)
}

\author{
Dede Hoerudin a,1,, Triono a,2, Paikun a,3 \\ ${ }^{a}$ Teknik Sipil, Universitas Nusa Putra Sukabumi, Indonesia \\ 1 dede.hoerudin ts17@nusaputra.ac.id *; ${ }^{2}$ triono@nusaputra.ac.id; ${ }^{3}$ paikun@nusaputra.ac.id \\ * Corresponding Author
}

Received 14 September 2020; revised 21 February 2021; accepted 31 March 2021

\section{ABSTRAK}

Perkembangan ilmu pengetahuan dibidang teknologi beton memungkinkan penggunaan limbah menjadi bahan dasar pembentuk beton, sehingga di satu sisi penggunaan bahan alam yang merusak lingkungan dapat diatasi dan di sisi lain bahan limbah dimanfaatkan seoptimal mungkin untuk bahan dasar pembentuk beton. Dalam penelitian ini variabel yang digunakan adalah variabel bebas yaitu variasi persentase limbah logam cement slag dalam campuran beton $(30 \%, 40 \%, 50 \%)$. Sample yang dibuat adalah beton keras dengan perbandingan komposisi campuran yang didapat sebelumnya dari hasil mix design beton normal yaitu dengan besar kuat tekan K-400 di uji pada umur 3, 7, dan 28 hari. Penelitian ini bertujuan untuk mengetahui berapa besar pengaruh limbah logam (cement slag) sebagai bahan pengikat hidrolik pada beton terhadap kuat tekan beton. Terdapat kenaikan kuat tekan pada umur 3, 7, dan 28 hari pada semua varian, Presentase terbaik Cement Slag sebagai campuran semen OPC yang menghasilkan kuat tekan beton silinder maksimal yaitu komposisi varian $30 \%$ karena mengalami kenaikan rata-rata $131 \%$ pada umur 28 hari dari kuat tekan rencana, sementara untuk full OPC mengalami kenaikan rata-rata $126 \%$ pada umur 28 hari dari kuat tekan rencana.

\section{K-400 Concrete Strength Analysis with Mixes Materials to Substitution Cement (Slag Cement)}

\section{ABSTRACT}

The development of science in the field of concrete technology allows the use of waste as the basic material for forming concrete, so that on the one hand the use of natural materials that damage the environment can be overcome and on the other hand the waste material is utilized optimally for the basic material for forming concrete. In this study, the variable used was the independent variable, namely the variation in the percentage of cement slag waste metal in the concrete mixture $(30 \%, 40 \%, 50 \%)$. The sample made is hard concrete with a mixture composition ratio obtained previously from the results of normal concrete mix design, namely the compressive strength $\mathrm{K}-400$ tested at the age of 3, 7, and 28 days. This study aims to determine how much influence metal waste (cement slag) as a hydraulic binder in concrete to the compressive strength of concrete. There is an increase in compressive strength at the age of 3,7 , and 28 days in all variants, the best percentage of Cement Slag as a mixture of OPC cement that produces the maximum cylindrical concrete compressive strength, namely variant composition of $30 \%$ because it has an average increase of $131 \%$ at the age of 28 the compressive strength of the plan, meanwhile for full OPC there is an average increase of $126 \%$ at the age of 28 days from the compressive strength of the plan.

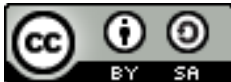

This is an open-access article under the CC-BY-SA license

\section{Pendahuluan}

Pencampuran bahan slag ke dalam semen portland bukan saja berarti meningkatkan nilai slag yang selama ini hanya dikenal sebagai bahan limbah, akan tetapi juga merupakan cara untuk menghemat energi yang diperlukan dalam proses produksi semen portland [1]. Perkembangan ilmu pengetahuan di bidang teknologi beton memungkinkan penggunaan limbah menjadi bahan dasar pembentuk beton [2], sehingga di satu sisi penggunaan bahan alam yang merusak lingkungan dapat diatasi dan di sisi lain bahan limbah 
dimanfaatkan seoptimal mungkin untuk bahan dasar pembentuk beton [3]. Slag yang merupakan hasil residu pembakaran tanur tinggi dari proses peleburan baja [4], salah satu limbah yang secara fisik menyerupai agregat kasar [5] . Seiring dengan perkembangan teknologi sampai saat ini sudah dihasilkan semen Portland slag. Secara volumentris beton diisi oleh agregat sebanyak 61-76\%. Jadi, agregat mempunyai peranan penting sebagai material pengisi beton. Seiring dengan semakin banyaknya pemakaian beton di dalam industri konstruksi maka semakin banyak dilakukan perubahan atau penggantian material campuran beton atau modifikasi beton yang diharapkan dapat meningkatkan mutu beton dan mereduksi permasalahan lingkungan [6].

Dari permasalahan inilah banyak alternatif yang dilakukan dalam penggantian material penyusun beton. Salah satunya adalah dengan mengganti sebagian bahan pengikat hidrolik (Portland Cement) yang biasa digunakan sebagai bahan pasta beton dengan menggunakan salah satu limbah industry logam yaitu slag cement [7]. Inovasi ini diharapkan berguna dan bernilai ekonomis tinggi dan salah satu cara terbaik untuk mengatasi masalah lingkungan. Kementerian Energi dan Sumber Daya Mineral (ESDM) memperkirakan limbah logam (slag) yang berasal dari pabrik pengolahan dan pemurnian (smelter) berpotensi mencapai 35 juta ton per tahun pada 2021, naik $75 \%$ dari saat ini 20 juta ton per tahun. Maka dari itu saat ini Pemerintah tengah mengupayakan mengeluarkan slag dari kategori limbah B3 dengan merevisi Peraturan Pemerintah No. 101 tahun 2014, agar slag dapat dimanfaatkan oleh industry [8]. Definisi slag atau terak dalam ASTM. C.989 adalah, "Standard specification for ground granulated BlastFurnace Slag for use in concrete dand mortar"[9]. ASTM, A995:494 adalah produk nonmetal yang merupakan material berbentuk halus, granular hasil pembakaran yang kemudin didinginkan[10]. Berdasarkan pembahasan di atas penulis meyakini bahwa limbah logam (Cement slag) dapat digunakan sebagai sebagian bahan pengikat hidrolik (pasta pengikat agregat halus dan kasar). Dengan menggunakan limbah logam (Cement slag) dapat mengurangi berat volume beton dan dapat meningkatkan mutu beton serta dapat mereduksi permasalahan lingkungan. Untuk membuktikan keyakinan tersebut, maka penulis akan melakukan penelitian dengan judul "Analisa kuat tekan beton k-400 dengan campuran material pengganti cement (slag cement)".

\section{Metode Penelitian}

Dalam penelitian ini variabel yang digunakan adalah variabel bebas dan variabel terikat [11]. Variabel bebas dalam penelitian ini yaitu variasi persentase limbah logam cement slag dalam campuran beton $(30 \%$, $40 \%, 50 \%)$ sementara variabel terikat dalam penelitian ini seperti semen, pasir, kerikil dan air. Sampel tiap variasi dalam penelitian ini adalah 9 benda uji silinder diameter $15 \mathrm{~cm}$ dan tinggi $30 \mathrm{~cm}$ [12]. Penelitian ini Mengikuti data-data dari studi pustaka baik Standar Indonesia SK SNI maupun standar asing yaitu ASTM. Sample yang dibuat adalah beton keras dengan perbandingan komposisi campuran yang didapat sebelumnya dari hasil mix design beton normal [13] yaitu dengan besar kuat tekan K-400 di uji pada umur 3, 7, dan 28 hari yang dapat dilihat pada Tabel 1.

Tabel 1. Spesifikasi Sample Penelitian

\begin{tabular}{ccccccc}
\hline \multirow{2}{*}{ Bentuk Sampel } & \multicolumn{2}{c}{ Ukuran $(\mathbf{m m})$} & \multicolumn{3}{c}{ Uji Kuat Tekan (Buah) } \\
\cline { 2 - 7 } & Diameter & Tinggi & Varian & Ke-3 & Ke-7 & Ke-28 \\
\hline Silinder & $150 \mathrm{~mm}$ & $300 \mathrm{~mm}$ & $30 \%$ & 3 & 3 & 3 \\
Silinder & $150 \mathrm{~mm}$ & $300 \mathrm{~mm}$ & $40 \%$ & 3 & 3 & 3 \\
Silinder & $150 \mathrm{~mm}$ & $300 \mathrm{~mm}$ & $50 \%$ & 3 & 3 & 3 \\
& Jumlah Sample & & & $\mathbf{9}$ & $\mathbf{9}$ & $\mathbf{9}$ \\
\hline
\end{tabular}

(Sumber: Olahan Penulis, Lab PT. Modern Panel Indonesia 2020)

Penelitian ini dilakukan pada bulan Februari sampai dengan April 2020 di Labotatorium Material dan Beton Batching Plant PT. Modern Panel Indonesia, yang berlokasi di Jl. Modern Industri XXVI No. 2 Kawasan Industri Modern Cikande, Serang Banten. Penelitian ini dilakukan dalam tiga tahap. Tahap 
persiapan, tahap pelaksanaan, dan tahap analisis dan pembahasan. Untuk lebih jelasnya dapat dilihat pada diagram alir tahap penelitian pada Gambar 1.

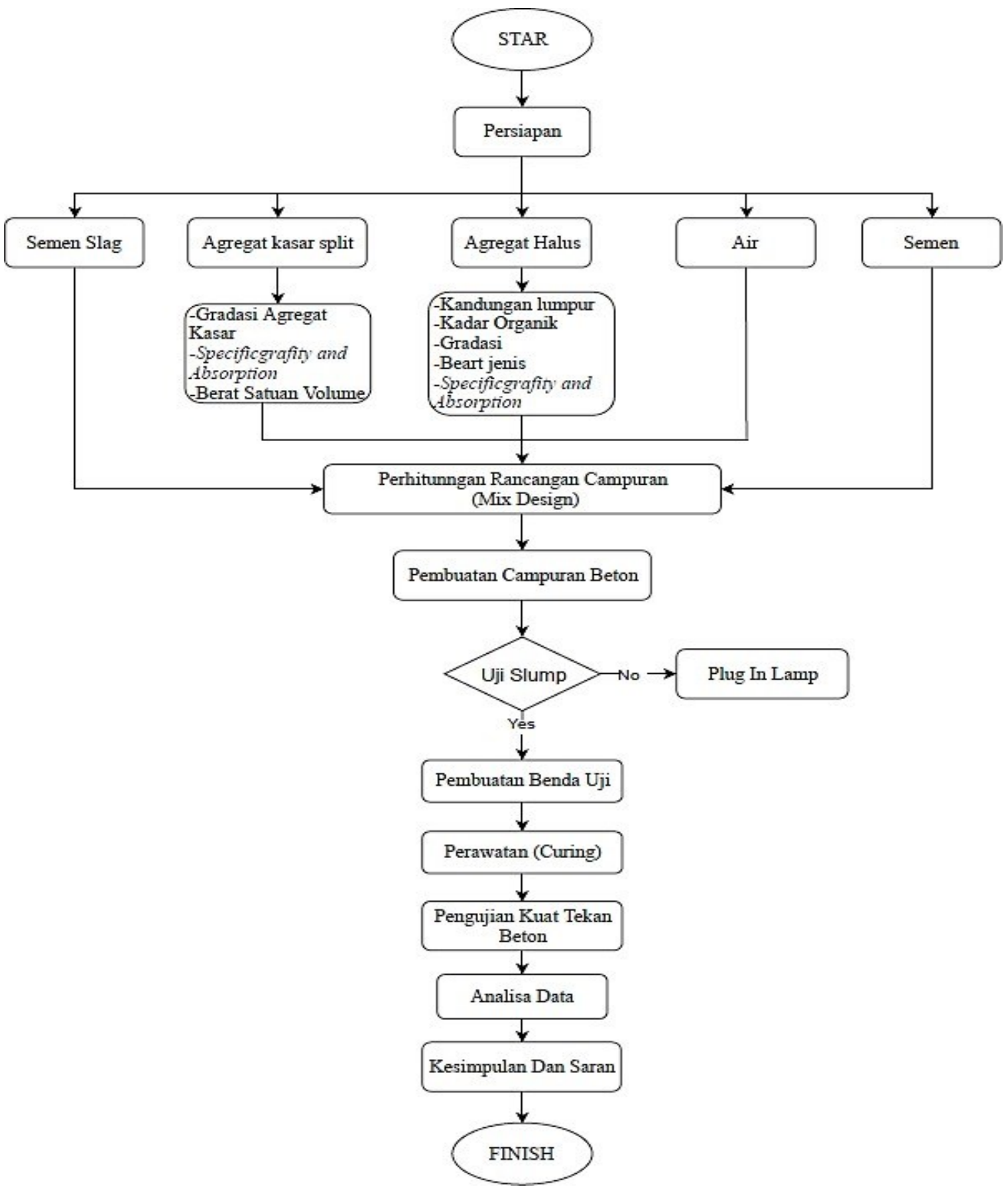

Gambar 1. Diagram Alir Penelitian

(Sumber: Olahan Penulis, Lab PT. Modern Panel Indonesia 2020)

\section{Hasil dan Pembahasan}

\subsection{Hasil Pengujian Bahan-Bahan Dasar Beton}

Hasil pemeriksaan atau pengujian terhadap bahan-bahan dasar beton yang dilaksanakan dilaboratorium meliputi: pemeriksaan atau pengujian agregat halus (Pasir Jambi). Serta pengujian agregat kasar yang berasal dari Desa Rumpin, Kab. Bogor dan Cement Slag. Pemeriksaan ini bertujuan untuk mengetahui kelayakan agregat sebagai bahan pembentuk beton. Hasil pengujian bahan-bahan tersebut 
dapat dilihat pada Tabel 2. Hasilnya memperlihatkan bahwa pengujian dari material ini telah sesuai dengan ketentuan yang berlaku.

Tabel 2. Hasil Pengujian Bahan Dasar Beton

\begin{tabular}{ccc}
\hline Jenis Pengujian Bahan & Hasil Pengujian & \multirow{2}{*}{ Keterangan } \\
\cline { 1 - 2 } Sem (ex. Merah Putih) & & Type 1 \\
Berat Jenis Semen & 3.15 & \\
Berat Jenis Semen Slag & 3.15 & \\
Agregat Kasar & ex. Rumpin & Kasar \\
Analisa saringan (FM) & 4.57 & Min. 2.30 \\
Berat Jenis (SSD) dan & 4.65 & Max. 5\% \\
Penyerapan (\%) & 2.3 & Max. 50\% \\
Keausan Agregat (\%) & 29.72 & Max. 5\% \\
Kadar Air (\%) & 2.65 & \\
Agregat Halus & ex. Pasir Tayan & \\
Analisa saringan (FM) & 2.73 & Pasir Sedang \\
Kadar Lumpur & 2 & Max. 5\% \\
Kadar Organik & 3 & Max. No 3 \\
Berat Jenis (SSD) dan & 2.64 & Min. 2.30 \\
Penyerapan (\%) & 0.91 & Max. 5\% \\
Kadar Air (\%) & 3.36 & Max. 5\% \\
\hline
\end{tabular}

(Sumber: Olahan Penulis, Lab PT. Modern Panel Indonesia 2020)

\subsection{Hasil Perhitungan Rencana Campuran Beton}

Dari hasil pengujian bahan-bahan beton baik hasil dari laboratorium atau yang sudah ada maka dapat dihitung rencana campuran beton dari agregat kasar split maupun Cement Slag. Seperti yang telah diuraikan diatas, bahwa rencana campuran beton (Mix Design) menggunakan standar American Concrete Institut dan buku Panduan Praktikum Bahan Bangunan ITI, Ir. Riana Herlina L, MT, Edisi II. Setelah mengetahui data- data pengujian bahan, maka akan diuraikan dengan perhitungan rencana campuran beton (Mix Design) dengan mutu rencana K 300. Dari perhitungan tersebut didapat kebutuhan bahan per $1 \mathrm{~m} 3$ yaitu seperti yang ada di Tabel 3 .

Tabel 3. Perbandingan Komposisi Mix Design

\begin{tabular}{|c|c|c|c|}
\hline Mutu Beton K400 & & K400 & K400 \\
\hline Deviasi Standar & $(\mathrm{Fc} 33,2) 7 \mathrm{MPa}$ & $(\mathrm{Fc} 33,2) 7 \mathrm{MPa}$ & $(\mathrm{Fc} 33,2) 7 \mathrm{MPa}$ \\
\hline Nilai Tambah (Margin) $1.64 \times 7$ & $11.48 \mathrm{Mpa}$ & $11.48 \mathrm{Mpa}$ & pa \\
\hline Slump Rencana & $10-15$ & $10-15$ & $10-15$ \\
\hline W/C Ratio & 0.46 & 0.46 & 0.46 \\
\hline Jumlah Air $\left(\mathrm{kg} / \mathrm{m}^{3}\right)$ & 194 & 194 & 194 \\
\hline Jumlah Semen $\left(\mathrm{kg} / \mathrm{m}^{3}\right)$ & 289 & 255 & 271 \\
\hline Jumlah Cement Slag $\left(\mathrm{kg} / \mathrm{m}^{3}\right)$ & 124 & 270 & 271 \\
\hline Jumlah Pasir $\left(\mathrm{kg} / \mathrm{m}^{3}\right)$ & 504 & 504 & 504 \\
\hline Jumlah MSand $\left(\mathrm{kg} / \mathrm{m}^{3}\right)$ & 168 & 168 & 168 \\
\hline Jumlah Kerikil $\left(\mathrm{kg} / \mathrm{m}^{3}\right)$ & 991 & 991 & 991 \\
\hline Consol Retarder 600D $\left(\mathrm{lt} / \mathrm{m}^{3}\right)$ & 1.01 & 1.01 & 1.01 \\
\hline
\end{tabular}

(Sumber: Olahan Penulis, Lab PT. Modern Panel Indonesia 2020)

Tabel 3 dapat dilihat bahwa untuk besaran nilai W/C semua varian nilai W/C nya sama berdasarkan kekuatan tekan yang diharapkan dan diameter agregat kasar maksimum. Pemahaman kuat tekan disini adalah kuat tekan rata-rata beton silinder. Seperti yang sudah diuraikan di atas, didapat bahwa hasil perhitungan campuran untuk adukan beton dapat dilihat pada Tabel 4.

Tabel 4. Proporsi Campuran Adukan Beton Setiap 1 Kali Adukan

\begin{tabular}{cccc}
\hline \multirow{2}{*}{ Uraian } & \multicolumn{3}{c}{ Kode Benda Uji } \\
\cline { 2 - 4 } & $\mathbf{3 0 \%}$ & $\mathbf{4 0 \%}$ & $\mathbf{5 0 \%}$ \\
\hline Jumlah Sample (Silinder) & $9+0.3$ & $9+0.3$ & $9+0.3$ \\
Air (kg) & 9.56 & 9.56 & 9.56 \\
Semen (kg) & 14,25 & 12.57 & 13,35 \\
\hline
\end{tabular}




\begin{tabular}{cccc}
\hline Semen Slag (kg) & 6.11 & 8.38 & 13,35 \\
Pasir (kg) & 24.84 & 24.84 & 24.84 \\
MSand (kg) & 8.28 & 8.28 & 8.28 \\
Kerikil (kg) & 48.83 & 48.83 & 48.83 \\
Consol Retarder 600D (l) & 0.05 & 0.05 & 0.05 \\
\hline
\end{tabular}

(Sumber: Olahan Penulis, Lab PT. Modern Panel Indonesia 2020)

\subsection{Hasil Pengujian Slump}

Pengujian ini adalah untuk memperoleh angka slump beton, yang dimaksud dengan angka slump beton adalah besaran kekentalan (Viscocity) plastisitas dan kohesif dari beton segar. Pengujian dilakukan dengan menggunakan kerucut Abrams dengan ukuran diameter atas $10 \mathrm{~cm}$, diameter bawah $20 \mathrm{~cm}$ dan tinggi $30 \mathrm{~cm}$. Dibawah ini akan diuraikan hasil pengujian slump dari 3 macam campuran beton yaitu beton dengan menggunakan Cement Slag dengan tiga varian yang berbeda. Yang dapat dilihat pada Tabel 5 dan Gambar 2.

Tabel 5. Hasil pemeriksaan Slump Test

\begin{tabular}{cc}
\hline Varian Cement Slag & Slump Rata-rata (cm) \\
\hline $30 \%$ & 11,5 \\
$40 \%$ & 12,5 \\
$50 \%$ & 13 \\
\hline
\end{tabular}

(Sumber: Olahan Penulis, Lab PT. Modern Panel Indonesia 2020)

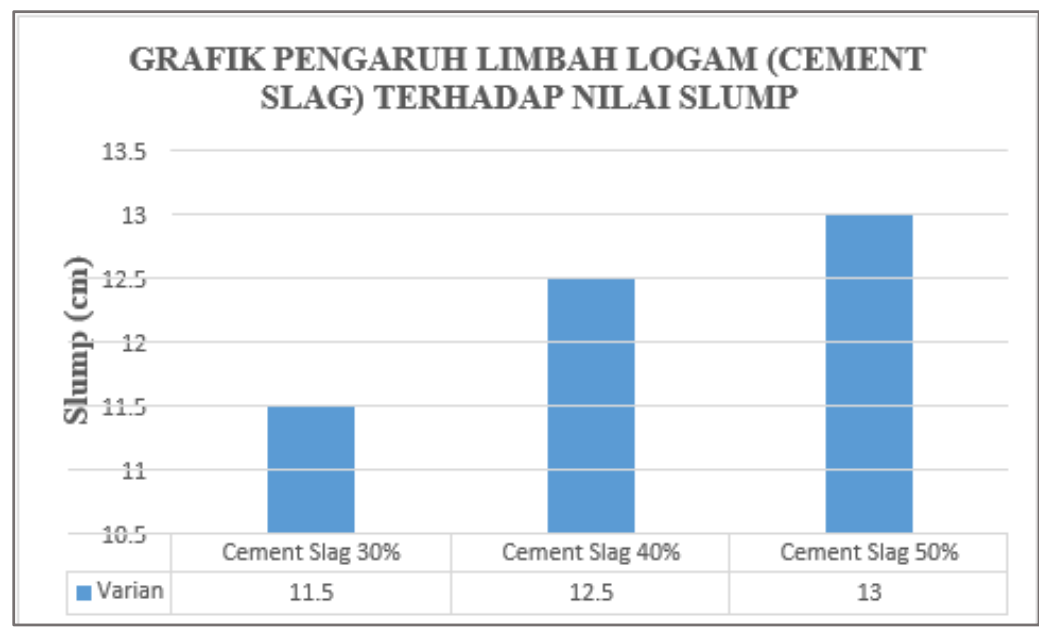

Gambar 2. Grafik Nilai Slump Test

Tabel 5 dan Gambar 2 memperlihatkan bahwa perbandingan nilai slump antara ketiga campuran beton di atas, yaitu campuran beton dengan menggunakan Cement Slag 30\% sebesar 11,5 cm dan untuk campuran beton dengan menggunakan Cement Slag 40\% sebesar 12,5 cm dan Cement Slag 50\% sebesar $13 \mathrm{~cm}$. Nilai slump dari ketiga campuran beton tersebut memenuhi kriteria dari slump rencana yaitu 10 $\mathrm{cm}-15 \mathrm{~cm}$.

\subsection{Hasil Pengujian Kuat Tekan Beton}

Pengujian kuat tekan dilakukan pada saat benda uji berumur 3 hari, 7 hari, dan 28 hari, pengujian masing-masing sebanyak 3 buah silinder dengan menggunakan Universal Testing Machine untuk mendapatkan beban maksimum yaitu beban pada saat beton hancur ketika menerima beban tersebut (Pmax). Untuk keperluan perhitungan kekuatan dan pemeriksaan mutu beton, maka ditetapkan dan dikonversikan terhadap beton umur 28 hari, seperti pada Tabel 6 . 
Tabel 6. Faktor Konversi Umur Beton [14]

\begin{tabular}{cccc}
\hline Umur Beton (Hari) & $\mathbf{3}$ & $\mathbf{7}$ & $\mathbf{2 8}$ \\
\hline Semen OPC (Type 1) & 0.4 & 0.65 & 1 \\
\hline
\end{tabular}

Hasil uji tekan beton pada umur 3 hari, 7 hari, dan 28 hari, dapat dilihat pada Tabel 7 dan Tabel 8 dengan keterangan dalam bentuk grafik dari 3 varian komposisi Cement Slag yang tersedia pada Gambar 3 dan Gambar 4.

Tabel 7. Kuat Tekan Beton Varian 30\%

\begin{tabular}{|c|c|c|c|c|}
\hline $\begin{array}{c}\text { Umur Beton } \\
\text { (Hari) }\end{array}$ & $\begin{array}{c}\text { Kuat Tekan } \\
\text { Beton }\left(\mathrm{kg} / \mathrm{cm}^{2}\right)\end{array}$ & $\begin{array}{l}\text { Kuat Tekan Rata- } \\
\text { rata }\left(\mathrm{kg}^{2} \mathrm{~cm}^{2}\right)\end{array}$ & $\begin{array}{c}\text { Kuat Tekan } \\
\text { Rencana }\left(\mathbf{k g} / \mathrm{cm}^{2}\right)\end{array}$ & $\begin{array}{l}\text { \% Kenaikan Tehadap } \\
\text { Kekuatan Rencana }\end{array}$ \\
\hline 3 & $\begin{array}{l}234.45 \\
211.57 \\
215.57\end{array}$ & 220.52 & 160 & $37.82 \%$ \\
\hline 7 & $\begin{array}{l}357.37 \\
347.81 \\
34578\end{array}$ & 350.32 & 260 & $34.74 \%$ \\
\hline 28 & $\begin{array}{l}543.18 \\
562.19 \\
512.79 \\
502.87\end{array}$ & 525.95 & 400 & $31.49 \%$ \\
\hline
\end{tabular}

(Sumber: Olahan Penulis, Lab. PT. Modern Panel Indonesia 2020)

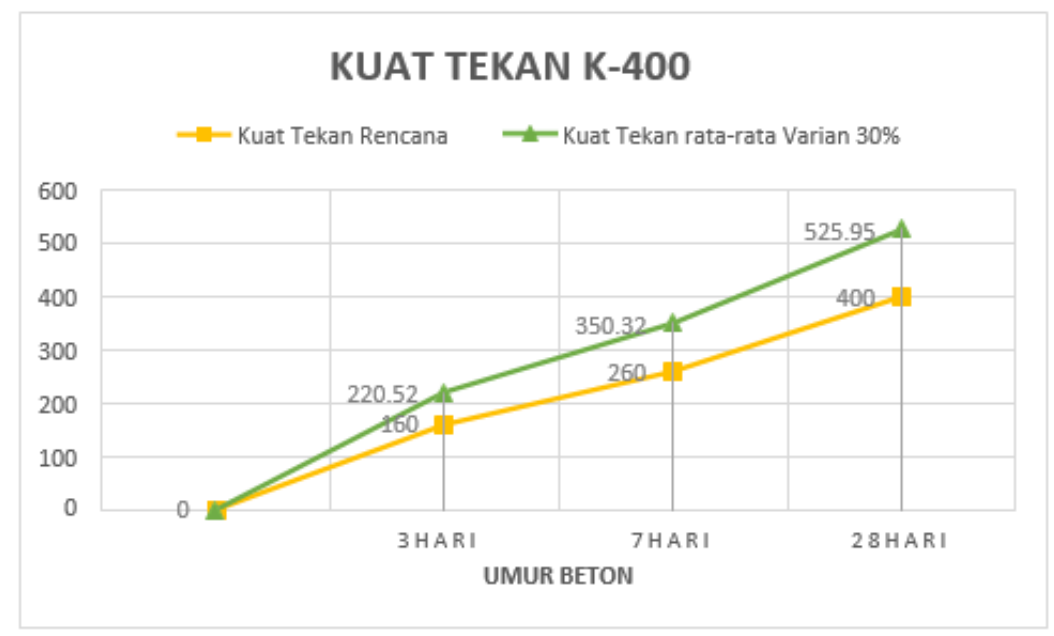

Gambar 3. Grafik kuat tekan beton varian $30 \%$

Tabel 7 dan Gambar 3, dapat dianalisa kekuatan tekan beton terhadap kuat tekan rencana untuk setiap umur beton. Grafik menunjukan kenaikan yang paling tinggi terjadi pada umur 3 hari sebesar $37.22 \%$, sedangkan pada umur 7 dan 28 hari terjadi penurunan masing-masing sebesar $34.74 \%$ dan $31.49 \%$. Seperti yang dapat dilihat pada Tabel 8 dan Gambar 4.

Tabel 8. Kuat Tekan Beton Varian 40\%

\begin{tabular}{|c|c|c|c|c|}
\hline $\begin{array}{c}\text { Umur Beton } \\
\text { (Hari) }\end{array}$ & $\begin{array}{c}\text { Kuat Tekan } \\
\text { Beton }\left(\mathrm{kg} / \mathrm{cm}^{2}\right) \\
\end{array}$ & $\begin{array}{l}\text { Kuat Tekan Rata- } \\
\text { rata }\left(\mathrm{kg} / \mathrm{cm}^{2}\right)\end{array}$ & $\begin{array}{c}\text { Kuat Tekan Rencana o/ } \\
\left(\mathbf{k g} / \mathbf{c m}^{2}\right)\end{array}$ & $\begin{array}{l}\text { \% Kenaikan Tehadap } \\
\text { Kekuatan Rencana }\end{array}$ \\
\hline 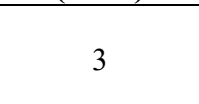 & $\begin{array}{l}257.31 \\
247.25 \\
23556\end{array}$ & 246.71 & 160 & $54.19 \%$ \\
\hline & $\begin{array}{l}235.56 \\
347.29\end{array}$ & & & \\
\hline 7 & $\begin{array}{l}335.90 \\
329.25\end{array}$ & 337.48 & 265 & $29.82 \%$ \\
\hline 28 & $\begin{array}{l}478.69 \\
499.57 \\
487.89\end{array}$ & 509.05 & 400 & $27.26 \%$ \\
\hline
\end{tabular}


(Sumber: Olahan Penulis, Lab. PT. Modern Panel Indonesia 2020)

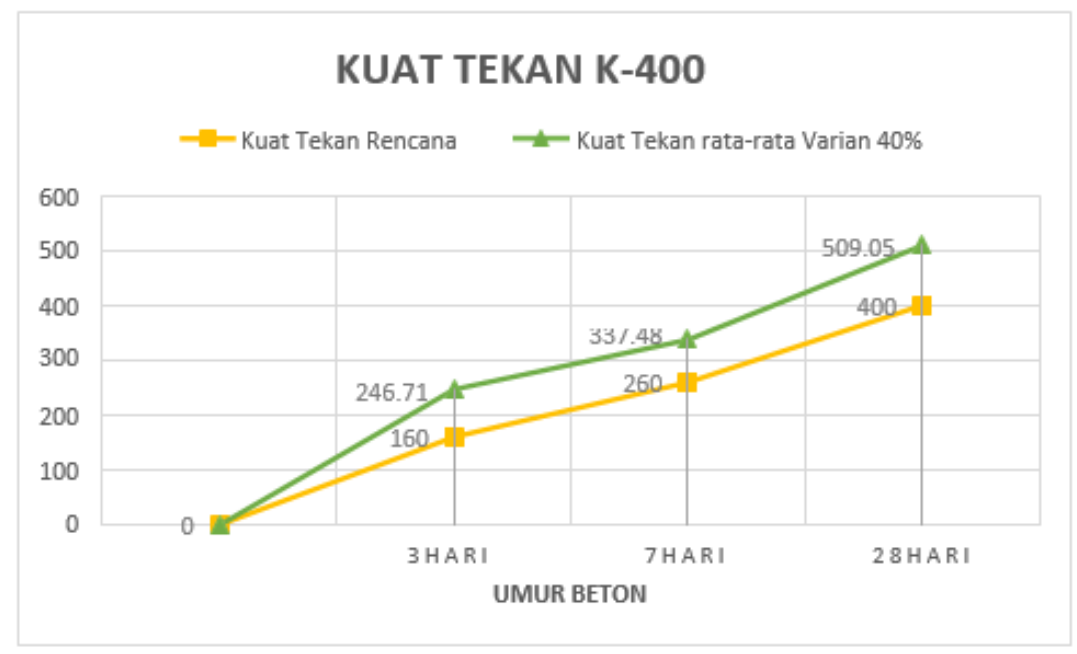

Gambar 4. Grafik kuat tekan beton varian $40 \%$

\subsection{Perbandingan Kuat Tekan Beton}

Perbandingan kekuatan tekan beton dengan menggunakan Cement Slag sebagai pengikat hidrolik dapat dilihat pada Tabel 9 dan Gambar 5 dan Gambar 6.

Tabel 9. Hasil Kuat Tekan Beton Dengan 3 Varian Berbeda

\begin{tabular}{ccccc}
\hline Kode Benda Uji & $\begin{array}{c}\text { Umur Beton } \\
\text { (Hari) }\end{array}$ & $\begin{array}{c}\text { Kuat Tekan Rata- } \\
\text { rata }(\mathbf{k g} / \mathbf{m} 2)\end{array}$ & $\begin{array}{c}\text { Kuat Tekan } \\
\text { Rencana }(\mathbf{k g} / \mathbf{m} 2)\end{array}$ & $\begin{array}{c}\text { \% Kenaikan Terhadap } \\
\text { Kekuatan Rencana }\end{array}$ \\
\hline \multirow{2}{*}{ Varian 30\% } & 3 & 220,52 & 160 & $37,82 \%$ \\
& 7 & 350,32 & 260 & $34,74 \%$ \\
& 28 & 525,95 & 400 & $31,49 \%$ \\
Varian 40\% & 3 & 246,71 & 160 & $54,19 \%$ \\
& 7 & 337,48 & 260 & $29,80 \%$ \\
Varian 50\% & 28 & 509,05 & 400 & $27,26 \%$ \\
& 3 & 322,51 & 160 & $101,57 \%$ \\
& 7 & 422,55 & 260 & $62,52 \%$ \\
\end{tabular}

(Sumber : Olahan Penulis, Lab. PT.Modern Panel Indonesia 2020)

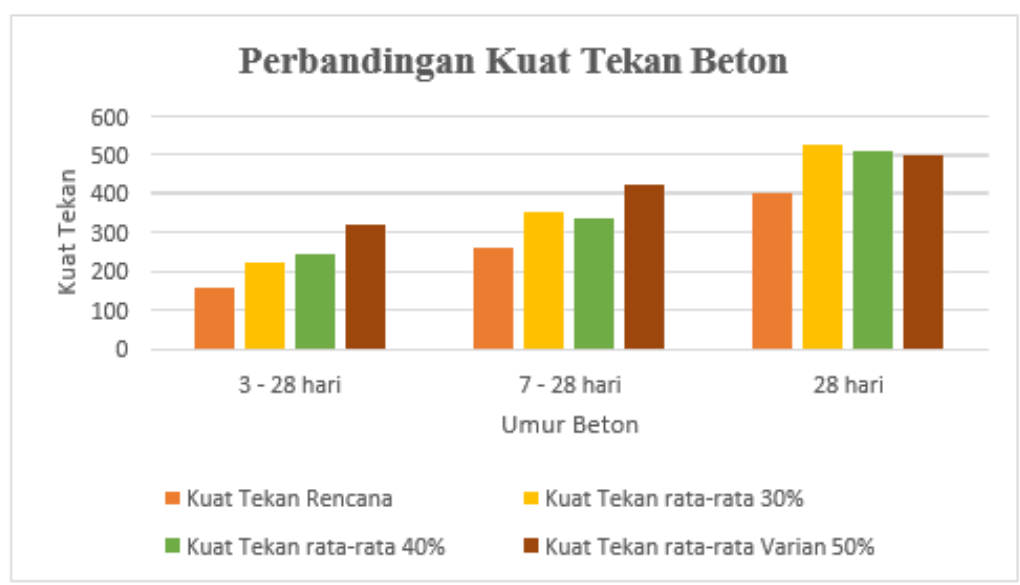

Gambar 5. Grafik perbandingan Kuat Tekan Beton Berbagai Umur 


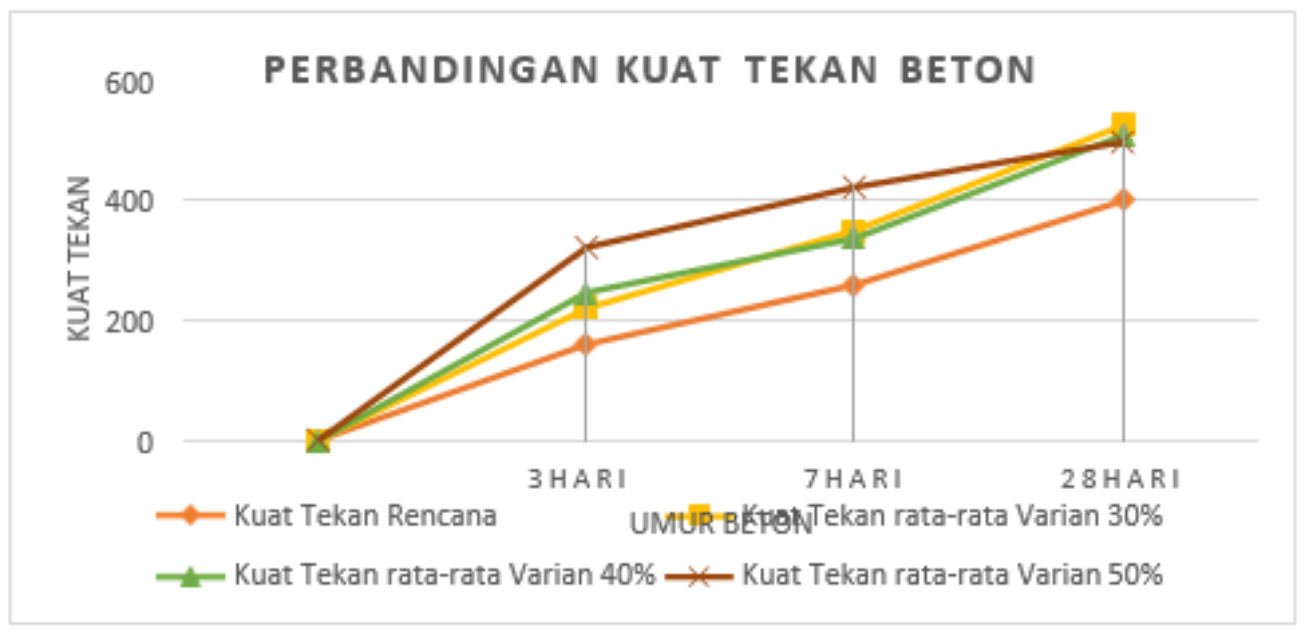

Gambar 6. Grafik perbandingan Kuat Tekan Beton

\section{Kesimpulan}

Peneletian ini membuktikan Slag Cement yang dibuat dari limbah logam dapat digunakan sebagai substitusi semen OPC dalam campuran beton. Penggunaan slag cement pada campuran beton yang telah diuji dengan varian campuran 30\%, 40\%, dan 50\% telah memenuhi kekutan bahkan cenderung mengalami peningkatan kekutan dari kuat tekan rencana baik diumur beton 3,7, maupun 28 hari. Peningkatan kuat tekan ini dipengaruhi karena slag yang dipilih adalah dengan Activity Index 120. Pengaruh penggunaan Limbah Logam Cement Slag pada campuran beton terhadap kuat tekan beton yang diperoleh setelah pengujian, terdapat kenaikan kekuatan dari semua varian. Presentase terbaik Cement Slag sebagai campuran semen OPC yang menghasilkan kuat tekan beton silinder maksimal yaitu komposisi varian 30\% karena mengalami kenaikan rata-rata 131\% pada umur 28 hari dari kuat tekan rencana, sementara untuk full OPC mengalami kenaikan rata-rata 126\% pada umur 28 hari dari kuat tekan rencana.

\section{Daftar Pustaka}

[1] N. R. Setiati and H. A. Halim, "Pemanfaatan Semen Portland Slag untuk Meningkatkan Sifat Mekanik dan Durabilitas Beton," J. Permukim., vol. 13, no. 2, pp. 77-89, 2018. Available at: Google Scholar.

[2] Y. Amran, "Pemanfaatan limbah plastik untuk bahan tambahan pembuatan paving block sebagai alternatif perkerasan pada lahan parkir di Universitas Muhammadiyah Metro," TAPAK (Teknologi Apl. Konstr. J. Progr. Stud. Tek. Sipil, vol. 4, no. 2, 2016. Available at: Google Scholar.

[3] P. S. Zalukhu, I. Irwan, and D. M. Hutauruk, "Pengaruh Penambahan Serat Sabut Kelapa (Cocofiber) terhadap Campuran Beton sebagai Peredam Suara," JCEBT (JOURNAL Civ. Eng. Build. Transp., vol. 1, no. 1, pp. 27-36, 2017. doi: $10.31289 / j c e b t . v 1 i 1.367$

[4] K. F. Banurea, "Pemanfaatan Limbah Baja (Slag Baja) Sebagai Bahan Campuran Aspal Terhadap Karakteristik Marshall." Universitas Medan Area, 2020. Available at: Google Scholar.

[5] M. N. F. Fauzi, "Pengaruh penambahan kerak tanur tinggi slag terhadap porositas dan permeabilitas beton geopolymer berbahan dasar abu terbang dan naoh 10 molar," Rekayasa Tek. Sipil, vol. 3, no. 3/REKAT/16, 2016. Available at: Google Scholar.

[6] T. Mulyono and M. T. Ir, "Teknologi Beton, CV," Andi Offset, Yogyakarta, 2004. Available at: Google Scholar.

[7] W. R. Lalu Mochamad, "Pengaruh penggunaan batok kelapa sebagai bahan pengganti sebagian agregat kasar terhadap sifat mekanik beton." Universitas Muhammadiyah Mataram, 2020. Available at: Google Scholar.

[8] L. S. Putri, "TA: valuasi nilai ekonomi total dari pemanfaatan limbah B3 slag baja sebagai bahan pengerasan jalan." Insttitut Teknologi Nasional Bandung, 2021. doi: 10.32672/jse.v6i2.2869 
[9] X. Wei, D. Li, F. Ming, C. Yang, L. Chen, and Y. Liu, "Influence of low-temperature curing on the mechanical strength, hydration process, and microstructure of alkali-activated fly ash and ground granulated blast furnace slag mortar," Constr. Build. Mater., vol. 269, p. 121811, 2021. doi: 10.1016/j.conbuildmat.2020.121811

[10] S. Mardoukhi and E. Alizadeh, "Effect of aqueous extract of Iranian Sumac (Rhus criaria L.) on the shelf life of Hypophthalmichthys molitrix fillet during storage at 4。 C," Iran. J. Fish. Sci., vol. 20, no. 3, pp. 615-627, 2021. Available at: Google Scholar.

[11] L. Prasetyo, F. R. Andardi, and N. H. Prima, "Pengujian Limbah Beton Sebagai Bahan Alternatif Agregat Berdasarkan Grafik Fuller," in Prosiding SENTRA (Seminar Teknologi dan Rekayasa), 2021, no. 6, pp. 33-39. Available at: Google Scholar.

[12] A. Faqihuddin, H. Hermansyah, and E. Kurniati, "Tinjauan Campuran Beton Normal dengan Penggunaan Superplasticizer Sebagai Bahan Pengganti Air Sebesar 0\%; 0, 3\%; 0; 5\% Dan 0, 7\% Berdasarkan Berat Semen," J. Civ. Eng. Plan., vol. 2, no. 1, pp. 34-45, 2021. Available at: Google Scholar.

[13] F. Berlianda, S. Saloma, and A. P. Usman, "Analisis mikrostruktur beton ringan kombinasi fly ash dan bottom ash." Sriwijaya University, 2021. Available at: Google Scholar.

[14] H. Hijriah and N. H. Yunianti, "Pemanfaatan limbah Iron Slag sebagai material pengganti sebagian pasir pada produksi beton," TAPAK (Teknologi Apl. Konstr. J. Progr. Stud. Tek. Sipil, vol. 10, no. 2, pp. 117-123, 2021. Available at: Google Scholar. 